\title{
INVESTIGATION OF THE WATERCOURSES AND MEASURES TO ALLEVIATE FLOODING IN THE PENAL/ DEBE REGION
}

\author{
Nadine Sangster ${ }^{1 *}$, Jorrel Bisnath ${ }^{2}$, Aatma Maharajh ${ }^{3}$, Allen Sammy \\ ${ }^{1,2,3}$ Design and Manufacturing Engineering, The University of Trinidad and Tobago, Trinidad \\ ${ }^{4}$ Penal/Debe Regional Corporation, Trinidad \\ ${ }^{1}$ Email: nadine.sangster@utt.edu.tt* \\ ${ }^{2}$ Email: jorrel.bisnath@utt.edu.tt \\ ${ }^{3}$ Email: aatma.maharajh@utt.edu.tt
}

\begin{abstract}
Flooding is a major concern for Small Island Developing States, particularly in the Caribbean region due to the tropical climate. The islands of Trinidad and Tobago, frequently experience severe weather conditions and of recent experience perennial flooding. Within the last three years, within Trinidad, the Penal / Debe region (PDR) has been affected by severe flooding, particularly in the year 2017 after Tropical Storm Bret, affecting the South Oropouche River Basin and so this region was chosen for this work. For this study, ten areas within the region were selected and a mix method comprising of both qualitative and quantitative research methods were utilized to gather data. It was found that businesses have incurred losses that amount up to TT $\$ 750,000.00$ while domestic residents have lost over TT $\$ 60,000.00$ worth of property during the incidents of flooding. The attributing factors for the flooding were determined as include the increased rainfall during the wet season coupled with the high tides and the sea level rise and watercourses within the area being clogged due to improper dredging and maintenance. The recommendations for alleviation of the flooding included a plan which looked at an education and awareness programme, dredging of the watercourses, the implementation of new water catchments, re-vegetation of damaged areas, the implementation of technology to improve monitoring and response and legislation to encourage best practices. Costings were performed for the various recommendations to allow for the region to make appropriate decisions regarding implementation.
\end{abstract}

Keywords: Flooding, Penal/Debe, Watercourses.

https://doi.org/10.47412/CHIF9112

\section{Introduction}

Small Island Developing States (SIDS) such as Trinidad and Tobago are victims of many natural disasters, the two most prevalent being hurricane and flooding. Trinidad is highly vulnerable to the climate change impact demonstrating deviations from regular rainfall patterns [1]. The rise in the sea level and the country's limited capacity to adapt to the severe weather conditions was revealed by the residents in the low terrain South Oropouche River Basin who were significantly affected by extreme flooding conditions. Over the past few years, flooding has particularly impacted residents of the Penal/Debe region tremendously causing losses to property, livestock and agriculture. The region is heavily populated with approximately 90,000 persons within 
$250 \mathrm{~km}^{2}$. This region comprises of several towns, some which are affected more than others thus the areas of interest within this study are:

1. Bronte

2. Rochard/Barrackpore East

3. Barrackpore West

4. Debe East/Esperance/Union Hall

5. Palmiste/Hermitage
6. Penal

7. La Fortune

8. Quinam/Morne Diablo

9. Debe West

10. Woodland

The work looked at possible causes of flooding, effects and recommendations regarding the alleviation of such in the area.

\section{Flooding and a Review of the Penal Debe Region}

Flooding may be caused by high amounts of and high intensity of rainfall, soil type and the runoff capacity which may be influenced by the relief of the land and man-made causes such as deforestation, slash and burn, poor land practices, urbanization - resulting in increased run-off, quarrying - excavation of land for the construction industry and improper waste disposal, for example, improper design of landfills and littering [2]. All of these causes have been found to contribute to the flooding in the PDR. The types of flooding which occur are riverine, flash and urban flooding. Mainly riverine and flash have occurred in the Penal/Debe region in the past however of recent urban flooding is being cited. In a ministerial report of the Penal-Debe Economic Profile [3] squatting, ribbon development and illegal constructions have been a major concern for the region. Reports state that as much as 50,000 persons may be found in the Woodland, South Oropouche and Fyzabad area alone. As a dormitory community, squatting created an influx of development which was unauthorized along many of the flood plains. Town and Country Planning Division (TCPD) had a restructure in the 2015 period which was a reaction created by their lack of control of the unauthorised developments in hillside and flood prone developments. While TCPD is charted with the responsibility to verify the construction of all structures on purchased lands, many loopholes are found where their involvement is averted. In a 2017 October 21st news article, the TCPD Director, Clyde Watche quoted "the mechanisms we have to deal with them have not worked as well as we would have liked."

\subsection{Watercourses in the Penal-Debe Region}

This study focused primarily within the Penal/Debe district. And so for the purposes presented here, the focus will be on the waterways, main rivers and tributaries which flow towards and into the Gulf of Paria through the Godineau River. Figure 2 below shows a topographic view of the area describing the contour of the land which is considered to be a main cause of flooding for citizens in lower lying areas. 


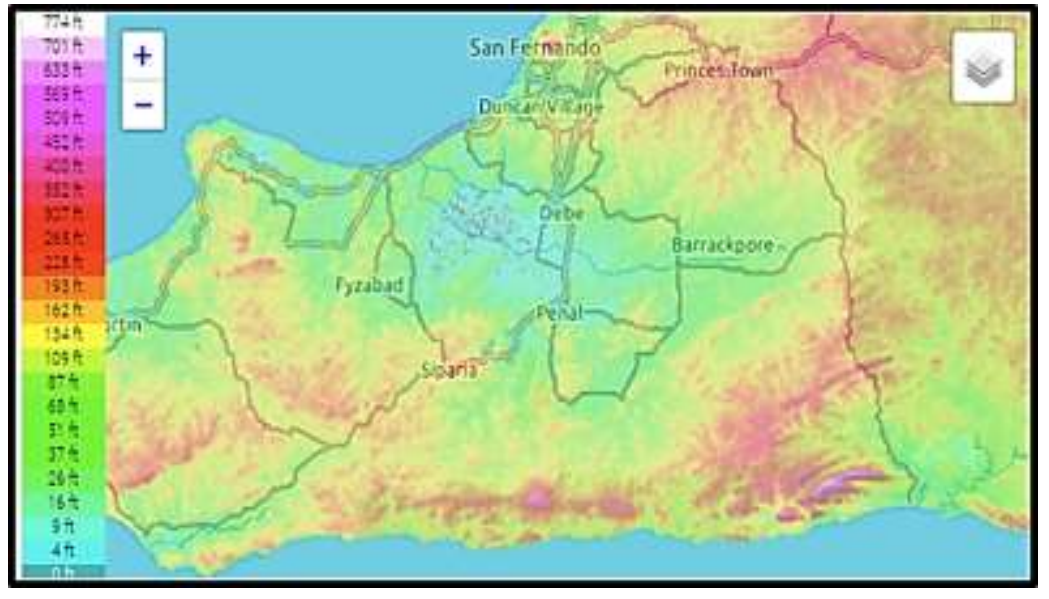

Figure 1: Topographic map of Penal-Debe region [4]

In correlation, with the topographic Map, the following is a flood susceptibility map highlighting the areas that are highly flood prone.

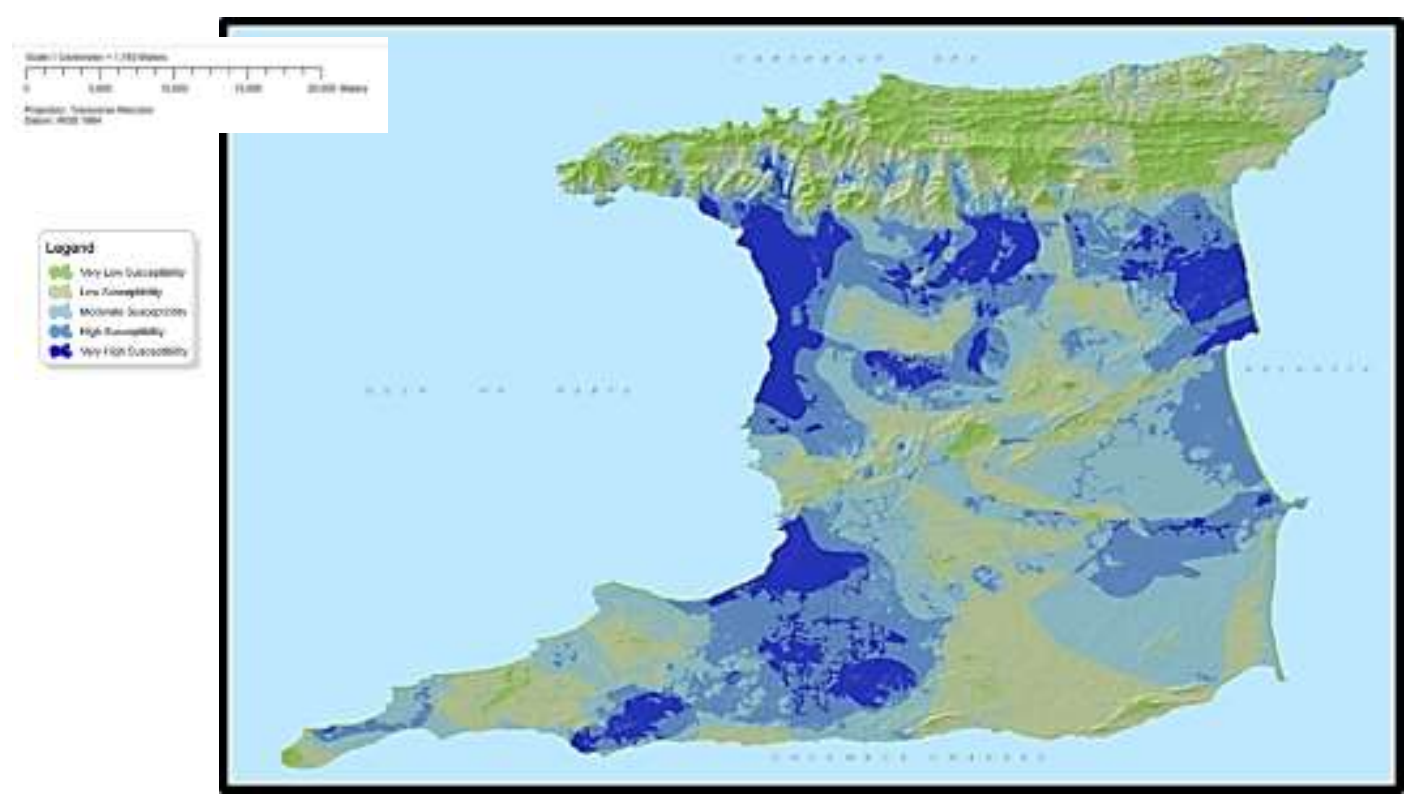

Figure 2: Flood susceptibility map of Trinidad and Tobago [5]

Figure 3 thus correlates with Figure 2 which shows that the lower lying areas in the region are susceptible to flooding.

\section{Data Collected}

Data was collected regarding the rainfall data and instances of flooding in the region. Figure 4 shows the rainfall pattern from 1991-2015 over the months. 


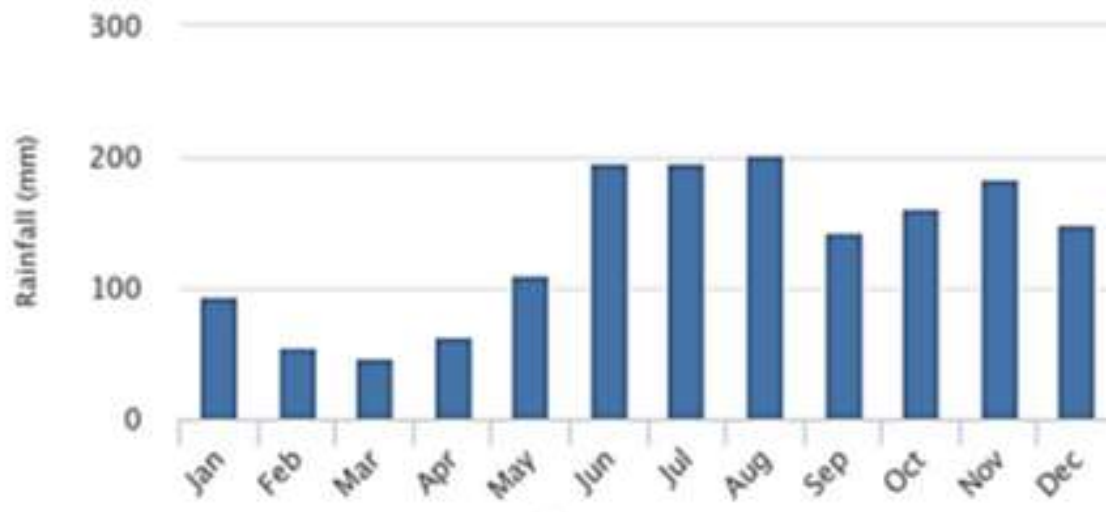

Figure 3: Average Rainfall for the period 1991 - 2015

The watersheds locally are shown in Figure 5 and looking at the municipal boundaries shown in Figure 6, about $60 \%$ of the Penal-Debe region falls within the South Oropouche watershed and is thus susceptible to flooding.

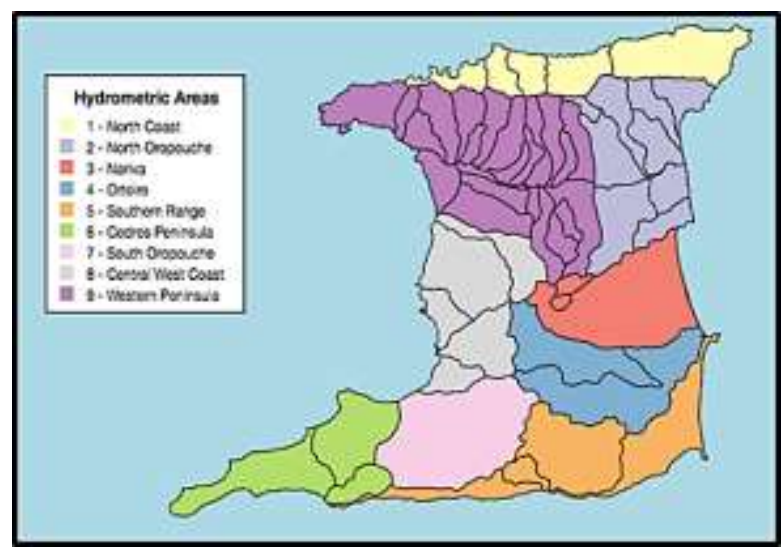

Figure 4: Watersheds of Trinidad [6]

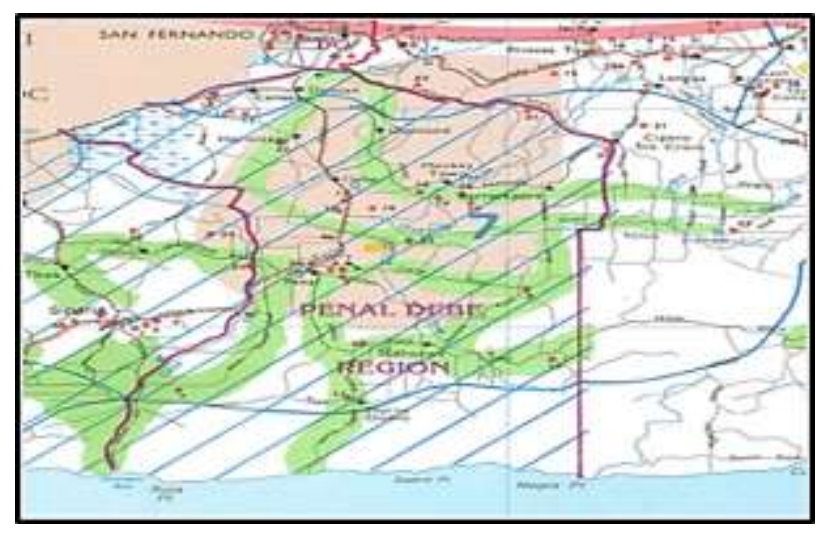

Figure 5: Municipal boundaries within South Oropouche Watershed [2]

\subsection{Flooding Occurrences in the Penal-Debe Region}


Figure 7 shows the occurrences of flooding from 2016 - 2018 and the corresponding causes.

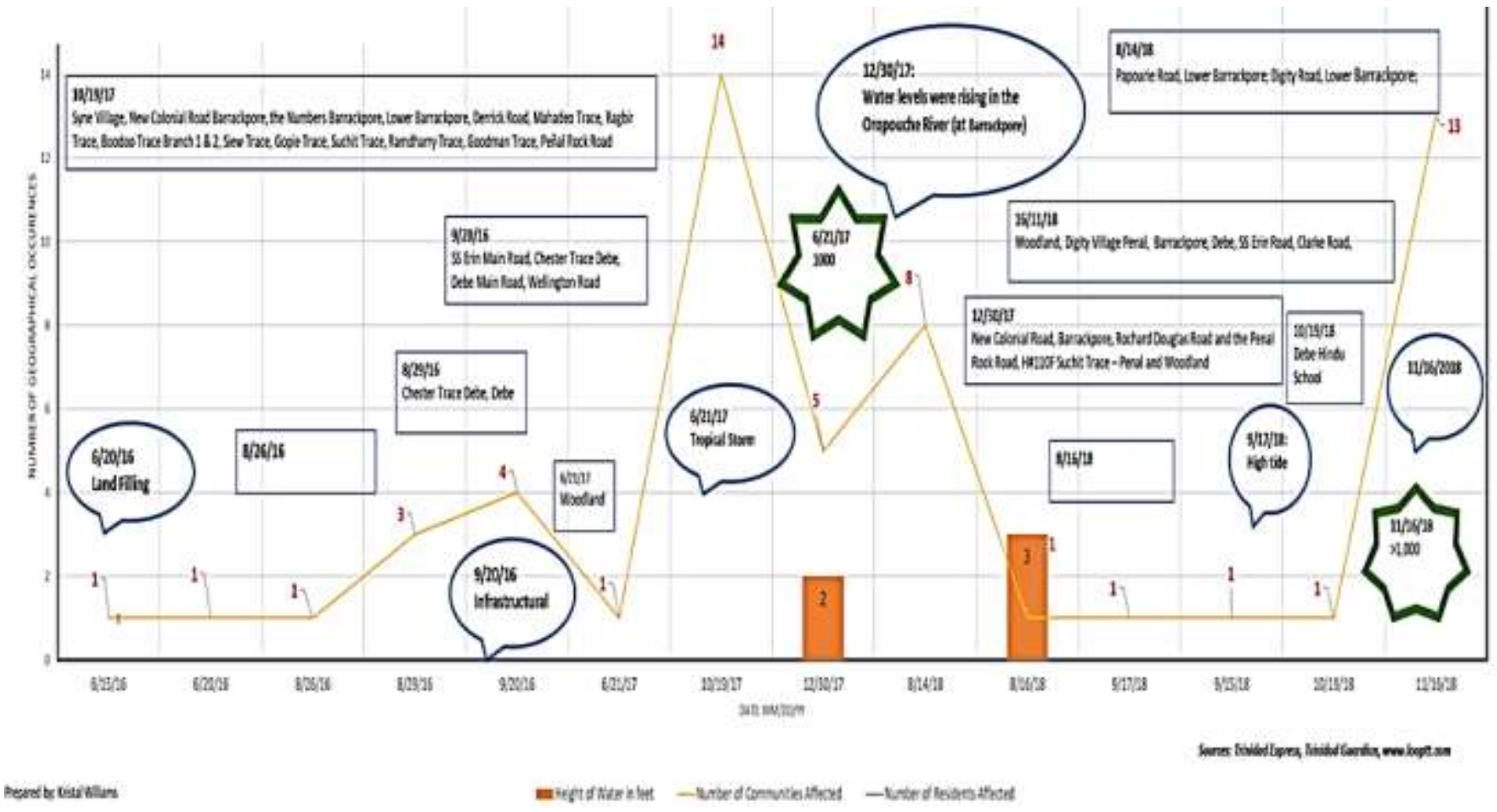

Figure 6: Instances and causes of flooding from 2016 to 2018 [7 - 11, 12 - 16]

Further to this a survey was done with 332 residents from the susceptible areas regarding the effect of the flooding in the region. Figure 8 shows how the residents perceived the flooding in the area.

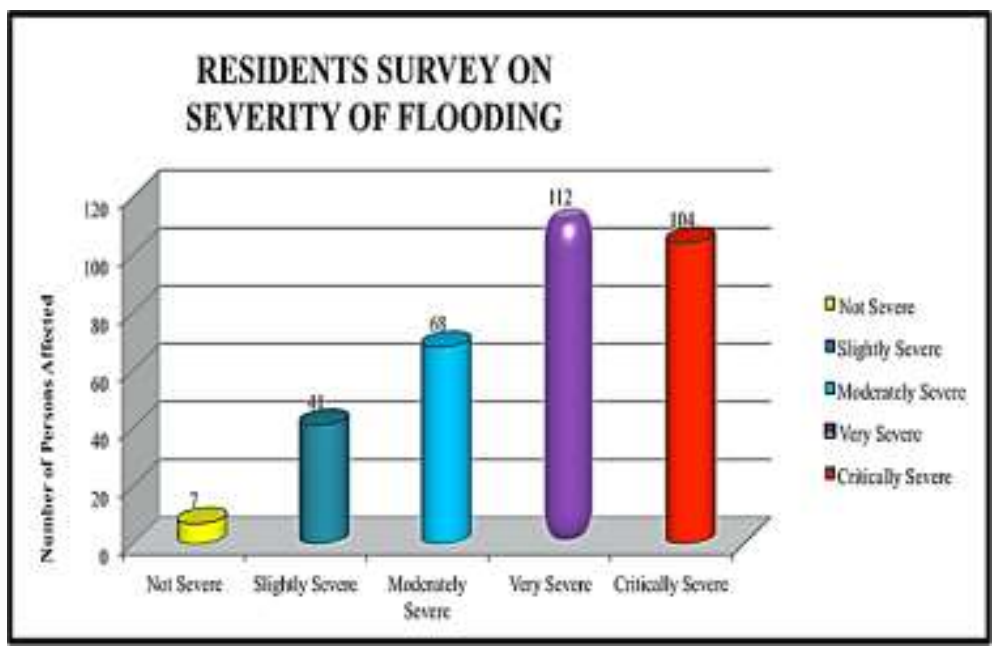

Figure 7: The severity of flooding within the Penal-Debe region expressed by the residents

The residents within the surveyed areas indicated that the severity of the flooding has been increasing over the three year period of this study. As illustrated by the graph, it is clear that the issue of flooding within this area is one of great concern. 
Residents were also asked about losses incurred due to flooding. Figure 9 shows the result and Figure 10 shows what they lost.
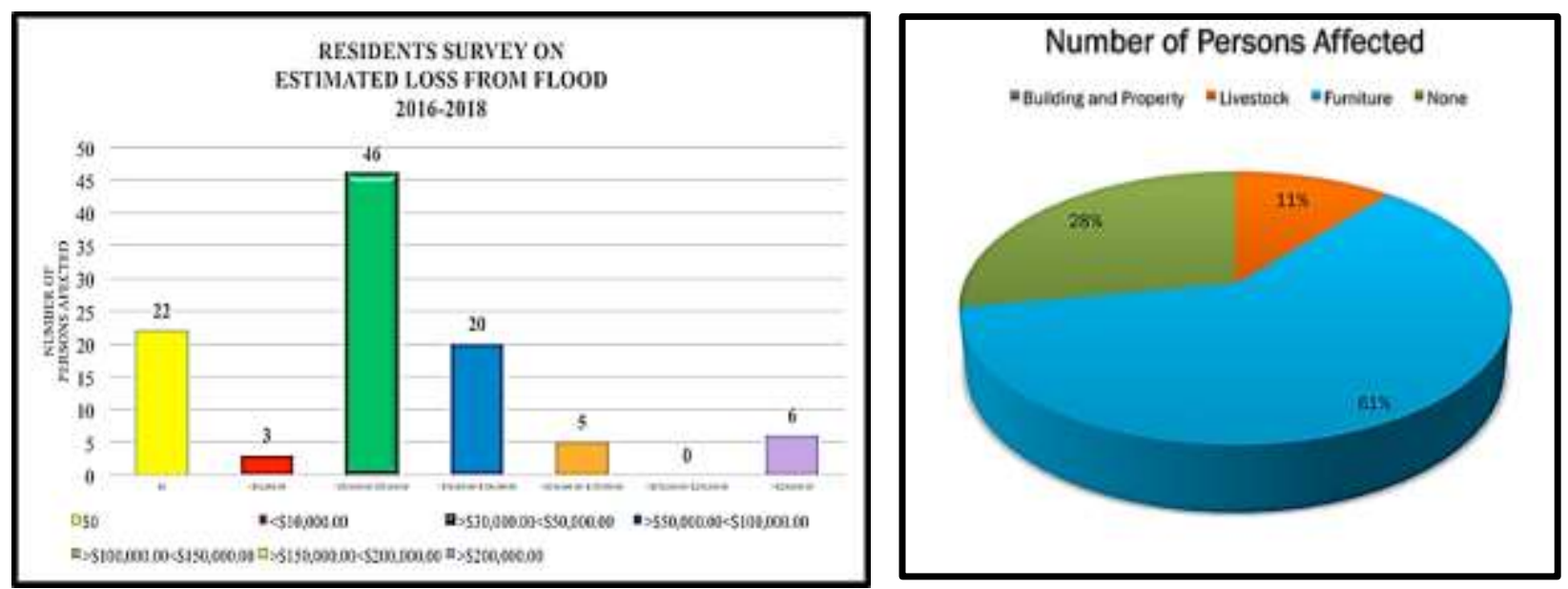

Figure 8: The estimated loss of the items flooding victims

Figure 9: Types of items lost

It was also observed that many residents have lost over sixty thousand dollars' worth of property more than once.

Residents were also asked what they perceived as the reason for flooding in the area and what they think could alleviate such. Figures 11 and 12 show what they said.

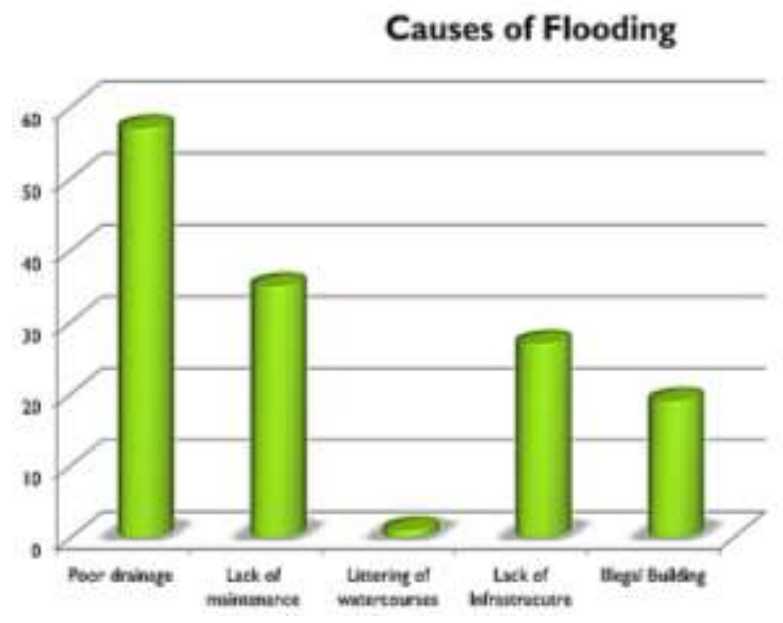

Figure 10: Residents' view of the causes of flooding

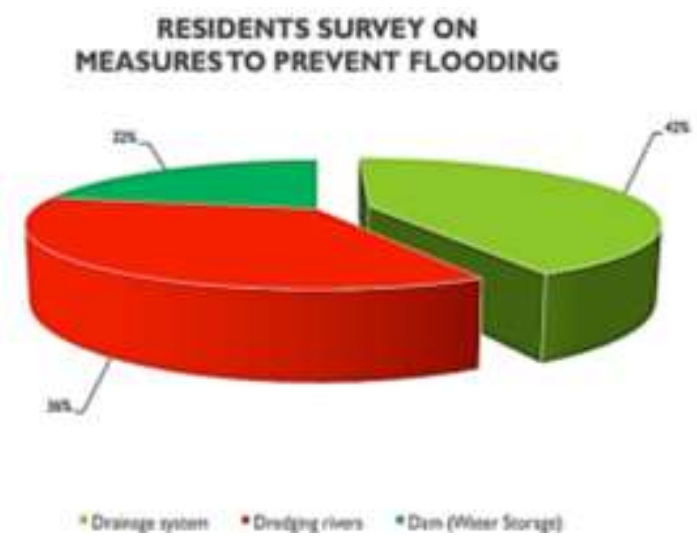

Figure 11: Residents' recommendations on the prevention of flooding 


\section{Findings and Recommendations}

A holistic approach is essential which includes the necessary governmental agencies to cooperate in order to reduce flooding within the region. This approach includes river/drainage maintenance using structural best practice, education for the residents and the use of flooding hardware. The following subsections outline the findings in the Penal Debe area with respect to the river/drainage maintenance.

\subsection{Drainage/Tributaries}

1. Under - sized drains - Main drainage along major roadways were built 50 years ago, however at that point there were not the quantities of businesses \& residents which are now located within the area. So the construction of buildings, backfilling of lagoons/low lying lands increased the surface runoff to the existing drains which were initially designed for smaller volumes of water. These "drains" can no longer facilitate water runoff as they appear to be just six inches in depth by two feet in width. The recommendation is to complete unfinished box drains, construct new ones and continue maintenance. This would serve to move the storm water to the relevant runoff point rather than into citizens' homes and business places.

2. Consistency of drainages - Upon touring the region, visiting areas from Barrackpore East, Rochard, Clark Road into Penal/Debe, the consistency of drains which accommodate water is not the same. Some sections of the drainages are narrower causing bottlenecking of the flow at those points and some are even dirt drains which may need to be upgraded eg. As in Figure 13.

3. Drain Maintenance - Visiting residents of the flood prone areas, along roadways poor drainage maintenance was observed. There were weeds, sand, dirt, bottles and other items trapped blocking major sections which were leading to main rivers. Some citizens saw it fit to clean the drainage in front their household, however, others did not. So timely cleaning of the existing drains is required. Additionally, suitable infrastructure development and appropriately engineered solutions such as box drains and other storm water catch pits are key to control the overflow of water that may affect villagers/residents.

If these drainage measures were to be implemented, they would contribute to alleviating flooding in and around the regional corporation. Areas identified for maintenance include:

- New Colonial Road Barrackpore,

- The Numbers Barrackpore,

- Lower Barrackpore,

- Derrick Road,

- Mahadeo Trace,

- Ragbir Trace,

- Boodoo Trace Branch $1 \& 2$,

- Siew Trace,

- Gopie Trace,

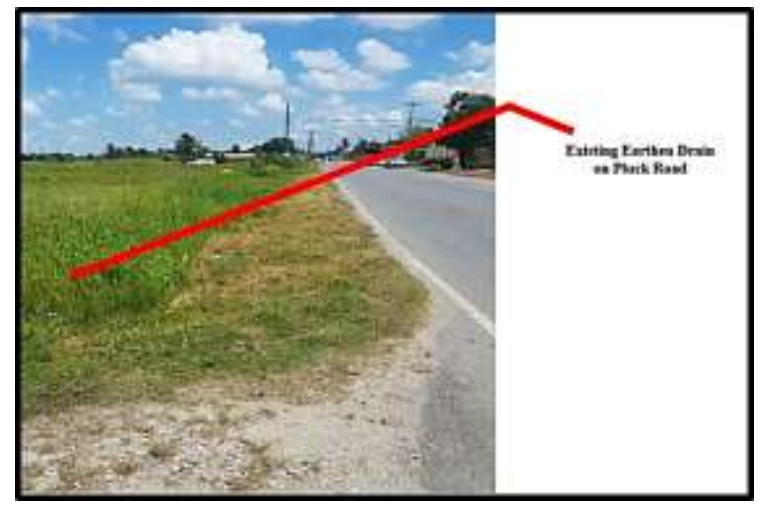

- Suchit Trace, 
- Ramdharry Trace,

- Goodman Trace,

- Penal Rock Road.

- Rahamut Road,

- Pluck Road.
Figure 12: Earthen drain on Pluck Road, La Fortune

\subsection{Rivers}

There are many tributaries entering into the two major rivers in the southern part of the island, namely the Godineau and the South Oropouche River. These rivers traverse quite a large volume of storm and inland water out into the Gulf of Paria and as such these rivers need to always be in such a state to bear this capacity without exceeding their banks and overflowing/ flooding villages, towns and generally any land area in the interior of the island. There is thus need for work to be done with respect to these rivers and they are outlined in the following subsections.

\subsubsection{Channelization}

This is simply defined as a method of river engineering that widens or deepens rivers (dredging) to increase the capacity for flow volume at specific sections of the river. As a result, when experiencing excessive volume of storm-water runoff, watercourses can run more efficiently and facilitate more water, which results in less damage to banks. Furthermore, channelization can provide erosion control and the rehabilitation of watercourses. Depending on the length and size of the river, costs of channelization and maintenance vary, but this can be one way in which entrepreneurship can be encouraged, for individuals who either purchase the necessary equipment to perform the dredging by working hand in hand with the regional corporation in executing these tasks. Properly consistent execution of land management is the key to alleviating the flooding within the Penal-Debe Regional Corporation. This should be done with the execution beginning at the source, continuing along the tributaries and deltas and finally being concluded at the mouth or exit point.

Dredging is the common practice that occurs in most cases as a reactive measure as opposed to that of a proactive measure, but in actuality local contractors for the most part usually just clear the debris and where possible and they only desilt the waterways.

\subsubsection{Re-develop the Meanders of the River}

This simply means that if the watercourses have no meanders and are on a straight run the flow of water from the source to the mouth would be moving at a rapid rate instead of traversing at a reduced speed having to manoeuvre around the meanders which would reduce flow rate speed resulting in the water having a more efficient and controlled run off versus just bursting and over spilling their banks at various points.

\subsubsection{Retaining Walls}

In addition to widening of the water courses areas such as the Bronte and Barrackpore areas further inland and the Woodland and St. John areas closer to the mouth of the river construct at strategic points the concrete retaining walls one being higher than the other to utilize the flood plains to 
channel the excess water on to the plains and not impacting on the villages and nearby communities. This would not be as costly as only in a few locations where there are flood plains to one side and developments on the other would these "concrete berms" and structures be implemented. This being done further inland and mid-way throughout the length of the river would again alleviate the flooding of these areas.

Utilizing all of the aforementioned, there could still be instances where due to excessive rain fall or adverse weather patterns still result in a substantial volume of water to flow into the Gulf of Paria which another recommendation of land management would be the "digging" or constructing a man-made delta parallel to the South Oropouche River (within the Oropouche Swamp area) in a straight run accessed by a flood gate in these instances to accommodate this access to have a straight and rapid flow out into the sea.

\subsubsection{Construction of Gabions and Reno Mattress}

This is an important factor for consideration for protecting properties by the river or creek. It aids to maintain, stabilise, and repair your river or stream bank. The riverbank supports and holds in the soil and prevents your land from washing away. Currently, riverbanks have been eroded by floods and debris, the continuing scouring causes problems not only to your land but also to the whole ecosystem. Gabions and Reno Mattresses are the ideal solution, especially for heavily eroded river and stream banks. Gabions are wire mesh baskets and are commonly filled with sandstone, bluestone or river pebbles. Gabion baskets were first industrially produced in the 1880's, when the double twisted wire mesh was first introduced. This particular double twisted woven netting ensures that in the event of a wire being cut, the double twist prevents the unravelling of the mesh. A stiffer and even stronger wire reinforces all the edges of the Gabion baskets. Reno mattresses are of similar construction but are usually wider with less depth. Unlike concrete, Gabions and Renos will not leach harmful chemicals into the water and will have a longer life span in the aquatic environment as they are PVC coated to prevent corrosion. Gabions are also naturally flexible, as they accommodate significant differential settlement and are permeable in their structure. As river sediments become trapped in the spaces between the rocks, vegetation growth is encouraged. The spaces also provide protective habitats for small aquatic creatures to live and lay their eggs.

\subsubsection{Retention Ponds/Dams}

The creation of retention and detention ponds along the Oropouche River where there are bottlenecks and excessive flow at major junctions from various tributaries entering into the river at which points there is a higher flow volume of storm water runoff. A collaborative project with the Water and Sewerage Authority (WASA) whereby a "retention area" or "mini dam" can be built at this junction as to serve as a secondary supply to "top up" the water supply in and around the regional corporation, especially when the usual water supply levels are depleted. This particular endeavour can be done by utilizing average rainfall data to calculate the volume of additional storm water entering into the river in addition to the capacity at the junction being channelled through those bottlenecks. The capacity of the river should be calculated during the dry season period to get a more accurate reading added to which in conjunction with the dredging, desilting, disposal of pollutants (inclusive of appliances, tyres, plastics etc.) and the removal of the overgrown 
vegetation that would have previously been narrowing the watercourse, to properly spec the river beds (where possible) to the required depth, resulting in the increasing overall capacity of the river. In addition to the cleaning and clearing of the rivers, the banks and or berms should be continually raised as well as institute vegetation such as coconut trees to strengthen these banks to prevent the constant erosion the banks. These ponds can be on a two-purpose basis. Firstly, the retention and detention ponds can be channelled further inland where there are now few developing communities to create and eco-park/water park and nature sanctuary that would not only provide entrepreneurial opportunities in building and operating the venue but employment of several persons to only have a positive impact on not only the localized community but the economy as a whole. The second option that these detention and retention ponds may provide would be that of a "storage facility" for the option of the re-introduction of rice farming as the soil in an around the regional corporation is ideal for the production and cultivation of rice farming.

\subsubsection{Vegetation}

Protection of wetlands and strategically planting of trees: The creation of wetlands acts like a sponge by soaking up moisture. The wooded areas can also slow down waters when rivers overflow. These areas are often destroyed for commercial development. Halting deforestation and wetland drainage, reforesting upstream areas and restoring damaged wetlands could significantly reduce the impact of climate change on flooding.

\subsubsection{Tackle climate change}

Climate change has contributed to a rise in extreme weather events. This also includes the rise in the sea level. In the 2016 Paris Agreement, governments pledged to pursue efforts to limit the increase in the global average temperature. By tackling the elements that contribute to climate change, the instances of flooding may be reduced.

\subsection{Education}

Going forward a collaboration of drives are needed to reinforce effective administration which includes community involvement in creating their own resilience against the flood entry and public education to echo the actions needed to address the alleviation of the intensified flooding events that occurred over the last few years. Citizens must also be educated regarding the importance of following the building codes of the land and how to properly dispose of solid waste.

\subsection{Flooding Hardware}

Internationally the use of flood hardware products such as flood barrier gates and level sensors and monitors are used to monitor, detect and allow for the management of flood waters. While locally we have some level meters installed in rivers, there is no "real-time" readings that are obtained from them. We thus need to harness the data from this type of measurement system and use it to anticipate and thus prevent damage that may be caused by flooding. 


\section{Conclusion}

There are many causes of flooding within the region that includes intense or heavy rainfall, relief or the contouring of the land and the soil type. The contouring of the land in the Penal-Debe region have been affected due to man-made interferences such as deforestation, poor land practices, urbanization, quarrying and improper waste disposal. As a result of the changes made to the landscapes, urban flooding is predominantly experienced. Flash flooding and riverine flooding also occur adding to the impact of the flooding.

Watercourses within the region were studied and in many instances it was observed that lack of maintenance and dredging of these watercourses added to the effects of flooding. Therefore, it was recommended that these watercourses be dredged prior to the rainy season. Additionally, for a long term recommendation, retention walls and berms should be constructed along the main Godineau River and the South Oropouche River the preliminary costs of this is approximately TT $\$ 17,000.00$. The use of Gabions and Renos was also studied as it provides a sound and stable structure. Meandering of these watercourses should also be considered as overflow of the river banks in several areas were observed. Along the smaller watercourses commercial construction works were evident where the watercourses were diverted improperly. The state intervention is required where the Town and Country building codes are enforced and adhered to. Furthermore, in many areas, a proper drainage system was not observed. Therefore, proper box drains should be implemented and an initial cost ranges from TT $\$ 1,000.00$ to TT $\$ 3,800.00$ depending on the size of drain required to effectively capture the water runoff.

Additional long term recommendations include the building of retention ponds or dams and an eco-reserve park such as that in the La Vega Estate in Gran Couva. Here, tourism can be boosted and it can also be as a form of recreation. This eco park can be viewed as an entrepreneurial venture. Finally, by incorporating the different recommendations described for both long term and short term, the prognosis for a massive flood free future for the residents of the Penal Debe Region is a good one. 


\section{References}

[1] ODPM, 2014 (version 01). Preliminary Vulnerability Assessment of Trinidad and Tobago. [2] NEMA (National Emergency Management Agency). (2004). Trinidad Hazard and Response Map. Retrieved November 19, 2017, from http://ontheworldmap.com/trinidad-andtobago/topographic-map-of-trinidad.jpg

[3] Penal/Debe Regional Corporation (2016). Penal/Debe Local Area Economic Profile Final Report. Retrieved from https://rdlg.gov.tt/wp-content/uploads/MLG-Penal-Debe-Final-LAEP.pdf [4] Topographic-map, (2018). Trinidad and Tobago Retrieved from: http://en-gb.topographicmap.com/places/Trinidad-and-Tobago-8262237/

[5] ODPM, (2011), Version 1. Flood Susceptibility Map: Trinidad. Retrieved from http://www.odpm.gov.tt/node/318

[6] Watertt, (2018). Watersheds in Trinidad and Tobago." Retrieved From: https://www.waterresourcestt.com/watersheds/

[7] V. Achibar, (2018). Debe residents counting flood losses. Trinidad and Tobago Newsday. Retrieved from: https://newsday.co.tt/2018/08/16/debe-residents-counting-flood-losses/

[8] C News, (2017). Hundreds affected by flood waters. Retrieved from: http://ctvtt.com/ctv/index.php/c-news/news/item/49415-hundreds-affected-by-flood-waters-inpenal-debe

[9] R. De Silva, (2018). Flood Waters rising across T\&T. Trinidad and Tobago Guardian. Retrieved from: http://www.guardian.co.tt/news/flood-waters-rising-across-tt6.2.695035.18d2c243al

[10] R. Dhalai, (2018). Floods in Penal, Barrackpore. Trinidad and Tobago Newsday. Retrieved from: https://newsday.co.tt/2018/11/15/floods-in-penal-barrackpore/

[11] Met Service, (2018). Climate. Trinidad and Tobago Meteorological Service. Retrieved from: https://www.metoffice.gov.tt/Climate

[12] S. Rampersad, (2016). Debe Floods Cause Thousands in damage. Trinidad and Tobago

Guardian. Retrieved from: http://www.guardian.co.tt/news/debe-floods-cause-thousands-

damage-6.2.355300.30e12fd789

[13] Reliefweb, (2017). Public Advisory \#4 - Saturday 30th December, 2017 - 7:00pm. Retrieved

From: $\quad$ https://reliefweb.int/report/trinidad-and-tobago/public-advisory-4-saturday-30thdecember-2017-700-pm

[14] S. Santoo, (2018). Flood fear rising in Penal/ Debe. Sunday Express. Retrieved from: https://www.trinidadexpress.com/news/local/flood-fear-rising-in-penal-debe/article_55d660c6ba80-11e8-b7f1-1bd79df48838.html

[15] Trinidad and Tobago Weather Center, (2017). Major flooding in the Penal/ Debe Region. Retrieved from https://www.facebook.com/TTWeatherCenter/posts/major-flooding-within-thepenaldebe-regionareas-affected-include-new-colonial-ro/1609713912381986/

[16] S. Wilson, (2016). Floods in Debe and POS. Trinidad and Tobago Guardian. Retrieved From: https://www.guardian.co.tt/news/floods-debe-and-pos-6.2.357392.86bc29c74a. 